\title{
Choosing an Ideal Graduate Education: The Nueva Ecija University of Science and Technology Experience
}

\author{
Jocelyn B. Cruz \\ Graduate School, Nueva Ecija University of Science and Technology, Cabanatuan City, Philippines \\ Email: subiagener@yahoo.com
}

How to cite this paper: Cruz, J.B. (2018) Choosing an Ideal Graduate Education: The Nueva Ecija University of Science and Technology Experience. Open Journal of Social Sciences, 6, 263-270. https://doi.org/10.4236/jss.2018.69018

Received: August 31, 2018

Accepted: September 22, 2018

Published: September 25, 2018

Copyright $\odot 2018$ by author and Scientific Research Publishing Inc. This work is licensed under the Creative Commons Attribution International License (CC BY 4.0).

http://creativecommons.org/licenses/by/4.0/

\section{(c) (i) Open Access}

\begin{abstract}
With the use of descriptive research, the researcher investigated the reasons of 152 freshman graduate school students in choosing NEUST for their graduate education. The respondents agreed that enrolling in NEUST Graduate Programs will make them good critical thinkers, collaborators, proficient speakers, responsible and productive citizens. Likewise, they have chosen the university because of its quality education, highly qualified teachers, affordable fees and high accreditation status. Efficiency of the services of the different offices was experienced by the respondents. However, they want to improve on the classroom condition, students' lounge, graduate school library schedule and library holdings. Likewise, they wished for accessible clean restroom per level of graduate school building.
\end{abstract}

\section{Keywords}

Collaborators, Critical Thinkers, Efficiency, Ideal Graduate Education, Quality Education

\section{Introduction}

Vital for every university in all corners of the world is understanding how students consider their school. Students "are the lifeblood of universities, and student characteristics often define the distinctiveness of individual campuses [1]". Additionally, "students of high academic ability are more likely to attend selective institutions as well as out of state institutions [1]".

Experts believe that the reputation and perceived high standard of a university are good basis of students in choosing a school for graduate studies. These are factors that professionals consider in entering an institution. But there are also 
other aspects worth considering such as quality of teachers, up-to-date teaching facilities, efficiency of services and geographical location of the school and the financial aspect. Most people are usually concerned about finances. Many students would want to attend public schools because of their cheaper tuition fee, while others prefer to attend private schools despite of high costs because of better learning facilities and equipment.

The purpose of graduate school according to [2] is "to help promising students become experts in some domain". "A graduate degree is increasingly considered an asset by employers and governments all over the world and opens up advanced leadership positions in the knowledge economy [3]". This is the reason why graduate students should carefully pick their institution since advance studies in a reputable university will help the professionals become specialists in their field and marketable in the workplace.

"Collaboration in the work place is one of the biggest factors that contribute to the success of any business" [4]. It is for this reason that aspiring graduate students should choose an institution that will train them to be good collaborators. Likewise, employees who are critical thinkers are sought after by employers nowadays. Their ability to engage in reflective and independent thinking [5] can be further enhanced if they could enroll in the right graduate school institution.

One of the sought-after state universities in Region 3 in the province of Nueva Ecija, Philippines that offers high level of graduate education (Level-3 Status) is the Nueva Ecija University of Science and Technology (NEUST). The university was established in 1908 and it is one of the four "Knowledge Eagle Universities of Nueva Ecija" [6] because it offers quality education to its clienteles. Its researches focused on "studies that will contribute to quality instruction, effective extension services, globally competitive technologies, good governance and curriculum development" [7].

Over the years, the Nueva Ecija University of Science and Technology (NEUST) Graduate School in Cabanatuan City, Philippines, has been posting a good number of enrollees in its masters' degree programs that include Master of Arts in Teaching (MAT), Master of Arts in English (MAE), Master in Business Administration (MBA), Master in Public Administration (MPA), Master of Science in Information Technology (MSIT), Master in Education Management (MEM) and Master in Engineering Management (MEnM). Course graduates are replaced by new enrollees such that the total number of students per semester practically remains constant. This phenomenon has raised questions: Is the NEUST Graduate School doing right by its program offerings that are able to maintain a regular number of loyal clienteles? In what aspects of the graduate department live up to the expectations of the students? And in what areas can it raise its ban for high graduate education services so that in the near future it will be at its peak of development and excellence [8]?"

It is in this context that this study was conducted. With the information secured from student themselves, covering areas that include reasons for their choice of NEUST, the problems encountered and suggestions offered for im- 
provement of the graduate school, the researcher as the current dean, she will be able to come up with plans of actions that will further improve its delivery of services to its clients. Gaining knowledge of how current students make their choices is important since this can aid university administrators in understanding the populace with the utmost interest in their institution and may also provide them with possible marketing strategies to attract the most highly qualified students possible. Additionally, "since perspectives change and cultural norms shift, this is an area of research that needs to be explored periodically to obtain current information [8]".

\section{Methodology}

This study utilized the quantitative approach of research using descriptive as its design. According to the authors in [9], "descriptive research is used to describe characteristics of a population or phenomenon being studied and addresses the characteristics of the population or situation being studied". The main tool used to gather data was a questionnaire based on the study conducted by the authors in [10]. However, modifications were done to suit the need of the study. The questionnaire has three parts. Part 1 is about the 21 st century skills that the respondents believed will be developed to them while studying in NEUST. The second part concerns the reasons of the respondents for choosing the university while the 3rd part is relating to the efficiency of the services encountered by the respondents during enrollment.

The responses were rated using the following scale:

\begin{tabular}{ccc}
\hline 3.25 to 4.00 & Agree & Efficient \\
2.50 to 3.24 & Moderately Agree & Moderately Efficient \\
1.75 to 2.49 & Slightly Agree & Slightly Efficient \\
1.00 to 1.74 & Disagree & Not Efficient \\
\hline
\end{tabular}

The content validation was made by experts in the field while the reliability of the instrument was established using Cronbach's alpha. The instrument was found to be reliable having reliability coefficients of 0.800 (for 21st Century Skills), 0.925 (for Reasons for Choosing NEUST) and 0.750 (for Efficiency of Services), respectively.

The respondents of the study who were selected using random sampling were 152 freshmen (58 males and 94 females) of NEUST Graduate School enrolled in the 1st semester 2018-19 under the programs Master of Arts in Teaching (MAT), Master of Arts in English (MAE), Master in Business Administration (MBA), Master in Public Administration (MPA), Master of Science in Information Technology (MSIT), Master in Education Management (MEM) and Master in Engineering Management (MEnM). NEUST is a state university located in Cabanatuan City, Nueva Ecija, Central Luzon, Philippines that offers graduate and undergraduate courses in many specialized fields and it is recognized as one of 
the four "Knowledge Eagle Universities of Nueva Ecija". Its graduate program linkages are expanding and include international entities as part of the expansion. "It has brought its graduate programs in China and has also hosted the South Korea's Master of Science in Information Technology, which is being offered at NEUST by the Hannam University [6]".

Data gathered from the respondents were analyzed using frequency, ranking and weighted mean.

\section{Results and Discussions}

\subsection{1st Century Skills that Respondents Believe Will Be Developed on Them While Studying at NEUST}

The respondents were asked about what 21st century skills they believe will be enhanced in them while getting their graduate education at NEUST and the result is shown in Table 1.

Among the nine skills identified, the respondents agreed that studying in NEUST will improve their critical and system thinking skills $(\mathrm{WM}=3.41$; Rank 1 ), interpersonal and collaborative skills ( $\mathrm{WM}=3.37$; Rank 2$)$, social responsibility (WM = 3.36; Rank 3) and communication skills ( $\mathrm{WM}=3.30$; Rank 4).

This means that the respondents are highly expecting that they will be trained in the graduate school of NEUST to become good critical thinkers and collaborators.

According to [11], "critical thinking is the ability to analyze the way you think and present evidence for your ideas, rather than simply accepting your personal reasoning as sufficient proof". He added that "an individual can gain numerous benefits from mastering critical thinking skills, such as better control of own learning and empathy for other points of view". On the other hand, collaborative persons are beneficial to the workplace and are the employers needed at the present time. The author in [12] argues that "progressive companies are increasingly realizing the value of collaboration in the prosperity of their business and looking for ways to foster collaborative spirit within their teams, both traditional and virtual".

Similarly, the respondents are anticipating that learning in NEUST graduate school will make them proficient speakers and responsible citizens. Communication skills in the 21st century was very vital for graduate students since it was mentioned by [13] in her article that "this is one of the top 10 skills employers seek for their employees to get the job". Likewise, to produce responsible and productive citizens who are skilled in research is one of the aims of NEUST graduate school [14].

\subsection{Reasons of the Respondents for Choosing NEUST for their Graduate Education}

The respondents were questioned about their reasons why they choose NEUST for their graduate education and the outcome is revealed in Table 2. 
Table 1. 21st century skills.

\begin{tabular}{lccc}
\hline \multicolumn{1}{c}{ 21st Century Skills } & WM & Verbal Description & Rank \\
\hline 1. Critical and System Thinking & 3.41 & Agree & 1 \\
2. Communication Skills & 3.30 & Agree & 4 \\
3. Accountability and Adaptability & 3.22 & Moderately Agree & 6 \\
4. Self-Direction & 3.20 & Moderately Agree & 7 \\
5. Problem Identification, Formulation and Solution & 3.23 & Moderately Agree & 5 \\
6. Interpersonal and Collaborative Skills & 3.37 & Agree & 2 \\
7. Information and Media Literacy Skills & 3.02 & Moderately Agree & 9 \\
8. Creativity and Intellectual Curiosity & 3.10 & Moderately Agree & 8 \\
9. Social Responsibility & 3.36 & Agree & 3 \\
Overall Weighted Mean & 3.25 & Agree & \\
\hline
\end{tabular}

Legend: 1.00 to 1.74 Disagree; 1.75 to 2.49 Slightly Agree; 2.50 to 3.24 Moderately Agree; 3.25 to 4.00 Agree.

Table 2. Reasons for choosing NEUST.

\begin{tabular}{|c|c|c|c|}
\hline Reasons for Choosing NEUST & WM & Verbal Description & Rank \\
\hline 1. NEUST offers quality education. & 3.50 & Agree & 1 \\
\hline 2. NEUST has high accreditation status. & 3.42 & Agree & 4 \\
\hline 3. NEUST has highly qualified teachers. & 3.44 & Agree & 2.5 \\
\hline $\begin{array}{l}\text { 4. NEUST trains the students about the real world of } \\
\text { work. }\end{array}$ & 3.25 & Agree & 5 \\
\hline 5. NEUST trains the students to be good and spiritual. & 3.08 & Moderately Agree & 8.5 \\
\hline 6. NEUST has affordable tuition and miscellaneous fees. & 3.44 & Agree & 2.5 \\
\hline $\begin{array}{l}\text { 7. NEUST trains the students to be catalysts in their field } \\
\text { of specialization. }\end{array}$ & 3.11 & Moderately Agree & 6 \\
\hline 8. NEUST has well known alumni. & 3.08 & Moderately Agree & 8.5 \\
\hline 9. Other people respect and admire NEUST's graduates. & 3.10 & Moderately Agree & 7 \\
\hline Overall Weighted Mean & 3.27 & Agree & \\
\hline
\end{tabular}

Legend: 1.00 to 1.74 Disagree; 1.75 to 2.49 Slightly Agree; 2.50 to 3.24 Moderately Agree; 3.25 to 4.00 Agree.

Rank 1 among the reasons why the respondents chose NEUST Graduate School is because the university offers quality education $(\mathrm{WM}=3.50)$. It is followed by the university has highly qualified teachers $(\mathrm{WM}=3.44)$ and the university has affordable tuition and miscellaneous fees. Next in rank is the university has autonomous status/high accreditation $(\mathrm{WM}=3.42)$. The finding clearly indicated that NEUST was chosen by the respondents due to its quality education, excellent teachers and affordable fees. Foskett et al. (2006) as cited by authors in [15] found that "students consider more carefully economic factors in times of distress and financial difficulty. These factors include job opportunities to supplement their incomes, accommodation costs and family home proximity. Third, course of study decisions tends to be closely related to institutional choice 
decisions". Likewise, the authors in [15] have "identified a range of factors influencing course preference course among employers; graduate satisfaction from the course; graduate employment from the course; the quality of teaching in the course".

In addition, high accreditation status of the university is another reason why the respondents are pleased to enroll at NEUST. "Accreditation is important especially to its graduates because it helps determine if an institution meets or exceeds minimum standards of quality; helps employers determine the validity of programs of study and whether a graduate is qualified. Employers often require evidence that applicants have received a degree from an accredited school or program [16]”.

\subsection{Efficiency of the Services Experienced by the Respondents during Enrollment}

The efficiency of the services experienced by the respondents during enrollment were asked by the researcher and the result can be gleaned on Table 3.

Efficiency of the services were experienced by the respondents particularly in the Cashier ( $\mathrm{WM}=3.45$; Rank 1); Enrolling Teacher/Department ( $\mathrm{WM}=3.44$; Rank 2); Graduate School (GS) Office (WM = 3.42; Rank 3); Accounting (WM = 3.33; Rank 4); and Registrar (WM = 3.27; Rank 5). This shows that NEUST offers quality services to its clienteles. According to [17], "efficient customer service is important because it promotes loyalty, provides accurate information, builds reputation and attracts new customers". A school like NEUST that provides quality service to its clients is expected to have an advantage over its competitors.

However, the respondents want improvement on the room assignments, students' lounge, graduate school library schedule and library holdings and they requested for accessible clean restroom per level of graduate school building.

\section{Conclusions}

Among the nine skills identified, the respondents agreed that studying in NEUST

Table 3. Efficiency of the services.

\begin{tabular}{lccc}
\hline \multicolumn{1}{c}{ Efficiency of the Service } & WM & Verbal Description & Rank \\
\hline 1. GS Office & 3.42 & Efficient & 3 \\
2. Enrolling Teacher/Department & 3.44 & Efficient & 2 \\
3. Clinic & 2.95 & Moderately Efficient & 6 \\
4. Accounting & 3.33 & Efficient & 4 \\
5. Cashier & 3.45 & Efficient & 1 \\
6. MIS & 2.93 & Moderately Efficient & 7 \\
7. Registrar & 3.27 & Efficient & 5 \\
Overall Weighted Mean & 3.26 & Efficient & \\
\hline
\end{tabular}

Legend: 1.00 to 1.74 Not Efficient; 1.75 to 2.49 Slightly Efficient; 2.50 to 3.24 Moderately Efficient; 3.25 to 4.00 Efficient. 
improves their critical and system thinking skills, interpersonal and collaborative skills social responsibility and communication skills. As to the reasons why the respondents chose NEUST Graduate School is because the university offers quality education with highly qualified teachers and the university has affordable tuition and miscellaneous fees and it has high accreditation status.

Efficiency of the services was experienced by the respondents particularly in the cashier, enrolling teacher/department, graduate school (GS) office, accounting and registrar's office. This shows that NEUST offers quality services to its clienteles. However, some respondents want improvements on the room assignments, students' lounge, graduate school library schedule and library holdings and requested for an accessible clean restroom per level of graduate school building.

\section{Acknowledgements}

The author would like to express her gratitude to Dr. Gener S. Subia, her statistician and critic, Dr. Manuela P. Gutierrez and Dr. Melissa M. Lepon, her editors, and Ms. Irene C. Damaso, her technical assistant.

Likewise, she wants to thank her respondents, all her colleagues at NEUST, especially the GS faculty and staff, her loving husband, Mr. Andres T. Cruz, and their children, Noah, Philip and Xandy, and their respective families, for their unending support and love.

Also, she wants to dedicate this paper to her two grandchildren, Shem Noeh and Thane Xander, who served as her inspiration and source of strength to finish this study.

\section{Conflicts of Interest}

The authors declare no conflicts of interest regarding the publication of this paper.

\section{References}

[1] Kinzie, J., Palmer, M., Hayek, D., Hossler, D., Jacob, S.A. and Cummings, H. (2004) Fifty Years of College Choice: Social, Political and Institutional Influences on the Decision-Making Process. Lumina Foundation for Education, Indianapolis, IN.

[2] Mumby, D. (2014) How to Choose the Right Graduate School Program. http://www.nextscientist.com/choose-graduate-school-program/

[3] TOPUNIVERSITIES (2013) The Benefits of a Graduate Degree. https://www.topuniversities.com/student-info/careers-advice/benefits-graduate-deg ree

[4] Boyer, S. (2017) The Importance of Collaboration in the Workplace. https://www.nutcache.com/blog/the-importance-of-collaboration-in-the-workplace/

[5] SkillsYouNeed.com (2011) Critical Thinking Skills. https://www.skillsyouneed.com/learn/critical-thinking.html

[6] Nueva Ecija University of Science and Technology-NEUST. (n.d.). https://www.triposo.com/poi/T__0b8f375c95cf 
[7] NEUST Graduate School. (n.d.).

http://neust.edu.ph/index.php/research/gen-tinio-st-campus/graduates-school

[8] Burdett, K. (2013) How Students Choose a College: Understanding the Role of Internet-Based Resources in the College Choice Process. University of Nebraska, Lincoln.

[9] Shields, P.M. and Rangarajan, N. (2013) A Playbook for Research Methods: Integrating Conceptual Frameworks and Project Management. New Forums Press, Stillwater, OK.

[10] Subia, G., Mangiduyos, G., Espiritu, J. and L. Arocena. (2016) Tracer Study on the Employability of College of Education Graduates of WUP from 2000-2014. AMALGAM Research Journal, 1, 1-11.

[11] Islam, R.S.M. (2015) What Are the Importance and Benefits of "Critical Thinking Skills"?

https://www.linkedin.com/pulse/what-importance-benefits-critical-thinking-skills-i slam/

[12] James, R., Baldwin, G. and McInnis, C. (1999) Which University? The Factors Influencing Choices of Prospective Undergraduates, Evaluation and Investigations Programme. Higher Education Division, Australia.

[13] Janet, J. (2015) Top 10 Qualities and Skills Employers Are Looking for Employment North: LAC Media.

[14] Subia, G., Florencondia, N., Trajano, M., Gutierrez, M. and Zabala Jr., B. (2018) Factors Associated with the Research Paper Writing Capabilities of Engineering Management and Vocational Technological Education Freshman Students. International Journal for Research and Development Technology, 9, Issue 3.

[15] Lee, S. and Chatfield, H. (2011) The Analysis of Factors Affecting Choice of College: A Case Study of UNLV Hotel College Students. William F. Harrah College of Hotel Administration University of Nevada Las Vegas.

[16] Accrediting Council for Independent Colleges and Schools (ACICS) (2010). http://www.acics.org/students/content.aspx?id=4320

[17] Why Is Effective and Efficient Customer Service Important? (n.d.). https://www.reference.com/business-finance/effective-efficient-customer-service-i mportant-d8b2ef94b1aff673\# 